\title{
Managing quality in university framework: Students' perspective
}

\author{
Mohammad Rumzi Tausif ${ }^{a}$ and Mohammad Imdadul Haque ${ }^{b^{*}}$
}

${ }^{a}$ Assistant Professor, College of Business Administration, Prince Sattam Bin Abdulaziz University, Saudi Arabia ${ }^{b}$ Associate Professor, College of Business Administration, Prince Sattam Bin Abdulaziz University, Saudi Arabia

C H R O N I C L E

\begin{tabular}{l} 
Article history: \\
Received: July 7,2020 \\
Received in revised format: \\
August 102020 \\
Accepted: August 17,2020 \\
Available online: \\
September 2, 2020 \\
\hline Keywords: \\
Saudi Arabia \\
TQM \\
Education \\
Quality \\
Logistic regression \\
\hline
\end{tabular}

\section{A B S T R A C T}

\begin{abstract}
Saudi Arabia is attempting to structurally transform itself to move away from its dependence on oil. Towards this, its education sector plays an important role. It provides the economy with the needed graduates. It is highly desirable that the education sector of the country attains and maintains quality standards. This study identifies the three dimensions of teaching staff, administrative staff and systems towards the Total Quality Management in a University setting. The study finds a significant difference between the sample respondents over the satisfaction with the faculty, staff, and systems. Further, the study uses the method of logistic regression to analyze the responses of University students' perspectives of quality. The results indicate that the odds of being satisfied with the University are the highest if the students are satisfied with the systems. It followed by faculty and then the non-teaching staff. Improving the quality of faculty, staff, and systems in education services is needed to achieve the structural transformation desired by the country.
\end{abstract}

C 2021 by the authors; licensee Growing Science, Canad

\section{Introduction}

The economic environment of Kingdom of Saudi Arabia is changing at a very fast pace (Tausif \& Haque, 2019). The Kingdom desires a huge expansion in all sectors of the economy. The Kingdom also plans to indigenize its labor force and is trying to improve the employability of its population (Kumar, et al., 2019). Hence, there is an enormous need for educated and skilled youth. In the recent past, the Kingdom has made tremendous expansion in the education sector. However, simply quantity without quality would be of not much use. The Kingdom announced a structural transformation program 'Vision 2030' in 2016 to reduce its dependence from oil. Quality of education will be a key factor for the success of Vision 2030. According to Vision 2030, the future aim for the educational services is "to nurture a generation of students who have values, appropriate basic skills of distinct specializations". The Kingdom aims to be a 'global model of excellence, on all fronts'. Regarding this, Vision 2030 endeavors that students; enjoy higher quality. The education sector is a different type of service sector. Here, the commodity to be consumed does not perish after some time. The value-added stays with the individual for life long. In addition, it has strong externalities associate with it. It has a role in the societal development of the country (Allam, 2020). In addition, the education sector of Saudi Arabia is different from other countries in terms of free education and the dominance of public universities. Universities are under a lot of pressure to become responsive and accountable for students' needs. Most educational institutions have to become more effective and efficient and must become student-centric. Most of the communitybased organizations, like educational, are now moving more rapidly toward transformations such as reengineering, crisis management, and installing total quality management (Alruwaili, 2013).

\footnotetext{
* Corresponding author.

E-mail address: $\underline{\text { m.haque@psau.edu.sa (M. I. Haque) }}$ 
The three factors of faculty, staff, and systems have been emphasized as the essential elements of quality in an academic institution (Weerasinghe \& Fernando, 2017). The teaching faculty plays a critical role in students' satisfaction (Gruber et al., 2012; Siming, 2015; Mihanović et al., 2016). Besides the teaching faculty, the role of the non-teaching staff has been commended by many studies. They have been referred to as the 'third space' by Whitchurch (2008). They also positively contribute to the student outcome (Graham \& Regan, 2016). In fact, there is a significant relationship between student's degree completion and the non-teaching staff to student ratio (Baltaru, 2019). Non-teaching staff is an important stakeholder in the context of TQM aspects at higher educational level (Almazan et al., 2017). Finally, systems like e-learning systems, learning management systems, and quality of institutional facilities also play an important role in maintaining quality in universities (Akhter, 2016; Alkhasawnh \& Alqahtani, 2019; Alsayyari, 2019).

Education without quality has no meaning (Tausif, 2017). The success of an academic institution is attributed to total quality management (TQM) (Al-Hazmi, 2020). TQM is a management philosophy which focuses on a customer-centric environment, which aims at customer satisfaction using continuous and all- round development. TQM refers to continuous improvements in processes and products (Hailu et al., 2018). Proper implementation of TQM has a meaningful and positive impact on organizational performance (Abdollahi et al., 2014). In the recent past, many researchers and quality experts have endorsed the use of Total Quality Management (TQM) in the education sector. Managing quality in higher education has been studied by quite a few researchers, Alkhalil and Oribe (2018), Inairat and AlKassem (2014), Qahtani and Al-Methheb (1999), to name a few. However, these are theoretical studies covering the descriptive aspects of TQM. This current study attempts to differentiate itself in terms of the application of managing quality in the higher education sector in the Kingdom through quantitative analysis. In the process, it explicitly uses the three aspects of teaching staff, administrative staff, and the systems in the satisfaction of students. The study identifies studying the elements of TQM in a University setting as its research problem. The objective of the study is to study the impact of three major dimensions, which affect the quality of education, quantitatively.

\section{Literature Review}

As per the study conducted by Jusoh (et al., 2004), the success of a service organization depends on their ability to constantly exceed or at least meet customer expectations. One big issue with service quality is that it cannot be measured or observed before consumption because of these comparing universities is practically not achievable (Zulkefli \& Uden, 2013). According to Sahney et al. (2008), education is not just a product, for various stakeholders and customers. According to research by Nasim (2019), detailed research recommended that quality improvement could be attained by incorporating all resources available outside and inside the University setup. According to Al-Shafei (et al., 2015) anywhere in the world quality and certification are extremely important for higher education institutes. Hence, developing a universal model for quality improvement in higher education is desired in the Kingdom. According to Chua (2004), teachers, students, parents, and future employers, all have different concepts regarding education quality. For teachers, quality is related to the whole system that includes the input, the output, and the process. However, for students, quality is more related to the process (methods of the teaching and curriculum). For parents, quality is more about the input like what is the reputation of the college, what is the ranking etc. however, for an employer's main aspect of quality is related to output, which includes what skills the students have. University education across the world is normally described as highly dynamic and turbulent. Global and local environmental factors are bringing changes across different countries and their university education systems (Brookes \& Becket, 2007). The students' perspective of the quality of education is taking center stage all over the world (Stukalina, 2012). In their study Jungblut (2015), opined that in the university education framework conceptualizations of quality depend on students' perspectives. According to Alhwairini and Foley (2012), irrespective of the type of organization, continuous improvement, and leadership approach is recognized as being vital for the successful application of (TQM). Five cornerstones of (TQM) were introduced by using a novel management TQM pyramid. These principles are continuous improvements, everybody participation, leadership, customer and employee focus, and focus on facts (Dahlgaard et al., 1995). Sallis (2002), feels that little incremental developments, help in accomplishing TQM. The TQM philosophy is huge, stimulating, and all-agreement; still, it's real implementation is small, incremental, and practical, rock-hard and long-term modification is based on a long sequence of small and achievable projects. According to Sangeeta et al. (2004), satisfying the students in an educational institution is the key idea of TQM. Nevertheless, few past researches have been doubtful of the applicability of applying TQM to educational setup and have found its application to be insignificant (Samuel \& Katrina (1995). Wiklund et al. (2003) opined that the most important characteristic of policy in higher education is quality improvement. However, the study identified that the various descriptions of TQM make the concept ambiguous, making it difficult to apply practically.

TQM has been functional mainly in the manufacturing area (Motwani \& Kumar, 1997). According to Todorut (2013), implementing TQM in the organization generates competitiveness. TQM can be used to manage the methods of the design, planning, and distribution areas. This will make organizations flexibility. By its very nature, higher education by its nature is a complex service. Managing the quality of higher education is complicated and many-sided (Zachariah, 2007). TQM has been implemented in higher education, in many colleges, research universities, and institutions. These institutions present success stories of improved morale, communication, improved productivity, better process efficiency, and reductions in cost and defects (Motwani \& Kumar, 1997). Universities can also play an important role in incorporating entrepreneurial intention among students (Tausif \& Haque, 2016). 
TQM offers fascinating restructuring opportunities for educators to discover (Herman \& Herman, 1995). The concept of TQM has also been used for the education sector of Saudi Arabia. Almurshidee (2017) feels there an immediate need to promote the culture of total quality. The two main notions of TQM are, first, continuous improvement, and second, the tools and techniques used (Wani \& Mehraj, 2014). According to Alseddiqi (2014), several universities in Saudi Arabia have put into practice TQM concepts but they are yet to achieve the benefits from it. Environmental analysis is required before implementation of the TQM process starts (Qahtani \& Al-Methheb, 1999). There is also a need to understand the student's satisfaction with the present system of education. Different tools can be used to measure satisfaction. According to De Oliveira and Ferreira (2009), in developing countries, there are grave quality complications and to correct this better-quality system is needed. According to Ilies (et al., 2010) until date, a debate is still on as how to strike a balance between the extent to which a university should educate according to the needs of current market needs or universities must avoid these materialistic pressures and teach students according to their own standards. Letcher and Neves (2010) opine that due to highly competitive pressure higher education institutes understanding the importance of students' satisfaction and they now understand that they are also part of the service sector. Alzamil (2014) feels that self-evaluation standards need to be developed to help educational institutions to assess their own performance. In a study conducted on private universities in Jordan, El Hawi and Alzyadat (2019) applied the concept of TQM to educational institutions through three items namely, development, participation, and evaluation. The results of the study show that the strongest influence on students' satisfaction was of participation variable. Sakthivel and Raju (2006) established a strong relationship between education quality, customer value, and student satisfaction. The quality of the staff, the quality of teaching, the quality of rules and laws, and the quality of students will improve the education process considerably (Alkhalil \& Oribe, 2018).

\section{Material and Methods}

A questionnaire is administered on the students of Prince Sattam Bin Abdulaziz University. A total of 507 questionnaires were collected back amongst which only 433 questionnaires were finally included in the analysis. The others were left out as they had incomplete responses. This study proposes to use Analysis of Variance (ANOVA) to look for differences amongst the satisfaction/dissatisfaction of the respondents with the teaching faculty, non-teaching supporting staff and systems of the college. Towards this, the null hypotheses (Ho) the study proposes to test for are:

1. Ho: There is no significant difference between the students in terms of satisfaction with the faculty.

2. Ho: There is no significant difference between the students in terms of satisfaction with the staff.

3. Ho: There is no significant difference between the students in terms of satisfaction with the systems.

The study proceeds with a questionnaire where the respondents are asked to submit their responses in Yes or No categories. Binary logistic regression is proposed to analyze the responses. The response on the dependent variable 'yes' is coded as 1 and the response 'no' is coded as ' 0 '. Maximum Likelihood procedure is used in this method. This method is a non-linear transformation of regression wherein the probabilities are constrained to lie between 0 and 1 . If the Odds ratio, denoted by $\operatorname{Exp}(\mathrm{b})$ is greater than 1, it signifies that the chance of the outcome will increase with an increase in the predictor. Similarly, if the Odds the ratio is lower than 1, it signifies that the chance of the outcome will decrease with an increase in the predictor. The equation for estimating the relationship is as follows:

$$
\ln \left\{\frac{p}{(1-o p)}\right\}=\alpha+\beta_{1}(\text { Faculty })+\beta_{2}(\text { Staff })+\beta_{3} \text { (Systems) }
$$

The study hypothesizes that the satisfaction of a student depends on satisfaction from three items namely faculty, staff, and systems in the University. The data is analyzed through SPSS 16.

\section{Result}

Table 1 provides a brief description of the data used. Out of the total of 433 students, 141 are satisfied with faculty, 241 are not satisfied and the remaining 51 are undecided about their Satisfaction/dissatisfaction with the faculty. The associated Fstatistic derived from Analysis of Variance (ANOVA) is also significant at a 5\% level of significance as it has a p-value of less 0.05 . This accepts the first hypothesis that there is a significant difference amongst the respondents over the satisfaction with the faculty. Similarly, 158 are satisfied with staff, 158 are not satisfied and the remaining 87 are undecided about their satisfaction/dissatisfaction with the staff. The associated F-statistic derived from Analysis of Variance (ANOVA) is also significant at a $5 \%$ level of significance as it has a p-value of less 0.05 . This accepts the second hypothesis that there is a significant difference amongst the respondents over the satisfaction with the faculty.

Table 1

$\underline{\text { Results of hypothesis testing }}$

\begin{tabular}{llllll} 
& Satisfied & Not satisfied & Can't say & F-Statistic & Sig. \\
\hline Faculty & 141 & 241 & 51 & 100.622 & 31.895 \\
Staff & 158 & 188 & 87 & 0.000 & 34.112 \\
Systems & 182 & 170 & 81 & 0.000 & 3 \\
\hline
\end{tabular}

Source: Author's calculation 
Finally, 182 are satisfied with the systems, 170 are not satisfied and the remaining 81 are undecided about their satisfaction/dissatisfaction with the systems. The associated F-statistic derived from Analysis of Variance (ANOVA) is also significant at a $5 \%$ level of significance as it has a p-value of less 0.05 . This accepts the second hypothesis that there is a significant difference amongst the respondents over the satisfaction with the faculty. A binary logistic regression was performed to ascertain the effects of faculty, staff, and system on the likelihood that the student is satisfied with the university. The model was statistically significant with a chi-square value of 187.174 with a P-value of less than 0.905 . The model explains $47 \%$ (Nagelkerke's R2) of the total variance in satisfaction. The model correctly classifies $78.8 \%$ of the total cases. Wald's test shows all the three variables are significant as faculty $(\mathrm{P}$-value $=0.023)$, staff $(\mathrm{P}$-value $=0.001)$ and the $\mathrm{P}$-value is 0.000 , which has a value of less than 0.05 . There is no coefficient listed, as faculty is not available. Rather dummy variables that represent faculty which code for faculty are in the equation and those have coefficients. The coefficient for one of the dummies is statistically significant while the other is not. The statistics given on this row tell that if the dummies that represent faculty are taken together are statistically significant. Because there are two dummies, this test has two degrees of freedom.

Table 2

Results of Logistic Regression

\begin{tabular}{|c|c|c|c|c|c|c|c|c|}
\hline \multirow{2}{*}{ Variables } & \multirow{2}{*}{ B } & \multirow{2}{*}{ S.E. } & \multirow{2}{*}{ Wald } & \multirow{2}{*}{$\mathrm{df}$} & \multirow{2}{*}{ Sig. } & \multirow{2}{*}{$\operatorname{Exp}(B)$} & \multicolumn{2}{|c|}{ 95.0\% C.I.for EXP(B) } \\
\hline & & & & & & & Lower & Upper \\
\hline Faculty & & & 13.188 & 2 & 0.001 & & & \\
\hline Faculty(1) & 0.783 & 0.345 & 5.154 & 1 & 0.023 & 2.188 & 1.113 & 4.302 \\
\hline Faculty(2) & $-.231-$ & 0.338 & 0.467 & 1 & 0.494 & 0.794 & 0.409 & 1.539 \\
\hline Staff & & & 13.76 & 2 & 0.001 & & & \\
\hline Staff(1) & 0.231 & 0.361 & 0.409 & 1 & 0.522 & 1.26 & 0.621 & 2.555 \\
\hline $\operatorname{Staff}(2)$ & $-.800-$ & 0.332 & 5.82 & 1 & 0.016 & 0.449 & 0.235 & 0.861 \\
\hline System & & & 73.315 & 2 & 0 & & & \\
\hline System(1) & 0.978 & 0.477 & 4.211 & 1 & 0.04 & 2.659 & 1.045 & 6.767 \\
\hline System(2) & $-1.680-$ & 0.387 & 18.878 & 1 & 0 & 0.186 & 0.087 & 0.398 \\
\hline Constant & 1.103 & 0.388 & 8.092 & 1 & 0.004 & 3.012 & & \\
\hline
\end{tabular}

Source: Author's calculation

The odd of being satisfied with the university is 2.188 times greater for those who are satisfied with faculty as opposed to those who are not satisfied with faculty. Similarly, the odd of being satisfied with the university is 0.449 times greater for those who are satisfied with staff as opposed to those who are not satisfied. Lastly, the odds of being satisfied with the systems is 2.659 times greater for those who are satisfied with systems as opposed to those who are not satisfied with systems at the University.

\section{Conclusion}

The study innovates through identifying the elements of total quality management (TQM) from students' perspective. The study proposes the following given below model for students' satisfaction in a University setting. In fact, all three dimensions namely systems, teaching faculty, and non-teaching staff are essential towards improving the delivery of education services. The result of this study validates the results of other studies that have found a relationship between these three factors with students' satisfaction. Although these three dimensions have different roles and different magnitude of impact on students' satisfaction, still all of them are significant. The study proposes the given below model to attain and assess quality in a university setup. Implementing similar studies in other universities would be the scope for future research.

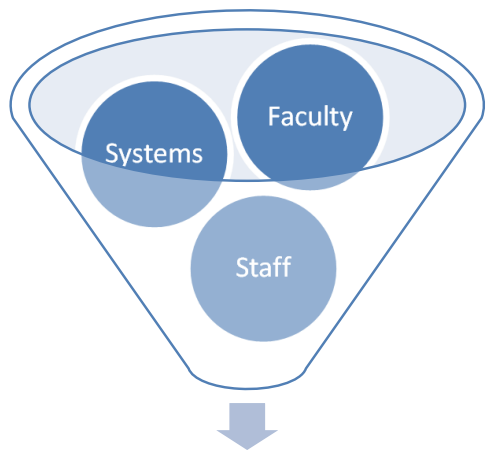

Students' satisfaction

The Kingdom of Saudi Arabia is striving to achieve its ambitious plan Vision 2030. According to Vision 2030 document, the Kingdom has given a lot of importance to education and quality of education. The Vision statement talks about providing high-quality education in line with the market needs; with results comparable to global education standards. In order to achieve 
Vision 2030, there is an immediate need to focus on the quality of education in the Kingdom. Focusing on students' satisfaction would help in improving the quality of educational services in the Kingdom. This study recommends improvements in systems, faculty, and staff for a continuous and overall improvement in the quality of education

\section{Acknowledgment}

This project was supported by the Deanship of Scientific Research at Prince Sattam Bin Abdulaziz University under the research project \# 2020/02/14323

\section{References}

Abdollahi, H., Razm, K., \& Tan, H.R (2014). TQM and market orientation's impact on SMEs' performance. Management Science Letters, 4, 887-892

Akhter, F. (2016). Designing information technology framework of enriching e-learning pedagogies. TEM Journal, 5(3), 379384.

Allam, Z. (2020). Demystifying the aspect of quality in higher education: Insights from Saudi Arabia. SAGE Open, 10(1), 2158244019899057.

Al-Hazmi, N. (2020). The effect of total quality management on marketing educational services in Saudi universities. Management Science Letters, 10(10), 2329-2336.

Alhwairini, A. and Foley, A. (2012). Working towards total quality management in Saudi Arabi. Education, Business and Society: Contemporary Middle Eastern Issues, 5(3),187-199.

Alkhalil, B., \& Oribe, Z. (2018). Total quality management in higher education in Kingdom of Saudi Arabia. International Journal of Computer Applications, 179(42), 30-33.

Almazan, C. G. O., Galangue, C. S., \& Bueno, D. C. (2017). Total Quality Management (TQM) in Practice at a Private Higher Education Institution in the Philippines. International Conference on Law, Business, Education and Corporate Social Responsibility (LBECSR-17) Sept. 21-22, 2017 Cebu (Philippines)

Almurshidee, K. A. (2017). The implementation of TQM in higher education institutions in Saudi Arabia: Marketing prospective. Global Journal of Management and Business Research, 17(1), 1-9.

Alkhasawnh, S., \& Alqahtani, M. A. M. (2019). Fostering students' self-regulated learning through using a learning management system to enhance academic outcomes at the University of Bisha. TEM Journal, 8(2), 662.

Alruwaili, J. (2013), Total quality management in education directorates in Saudi Arabia: Contrasting provincial case studies. Public Policy and Administration Research, 3(6), 26-34.

Alsayyari, A., Alblawi, A., Nawab, M., \& Alosaimi, A. (2019). A conceptual framework for facility management in Higher education institutions in Saudi Arabia. TEM journal, 8(1), 157.

Alseddiqi, A. R. G. (2014). Implementation of TQM in Public Universities of Saudi Arabia: Challenges and Resolutions (Doctoral dissertation, Kulliyyah of Economics and Management Sciences, International Islamic University Malaysia).

Al-Shafei, A.I., Abdulrahman, K.A., Alqumaizi, K.I., \& El-Mardi, A.S. (2015) Developing a generic model for total quality management in higher education in Saudi Arabia, Medical Teacher, 37(sup1), S1-S4,

Alzamil, Z. A. (2014). Quality improvement of technical education in Saudi Arabia: self-evaluation perspective. Quality Assurance in Education, 22(2), 125- 144.

Brookes, M., \& Becket, N. (2007). Quality management in higher education: A review of international issues and practice, The International Journal for Quality and Standards, 1: 1-37.

Chua, C. (2004), Perception of Quality in Higher Education, Proceedings of the Australian Universities Quality Forum: 1-7

Dahlgaard, J. J., Kristensen, K., \& Kanji, G.K. (1995). Total quality management and education. Total Quality Management, $6(5), 445-456$.

Graham, C., \& Regan, J. A. (2016). Exploring the contribution of professional staff to student outcomes: a comparative study of Australian and UK case studies. Journal of Higher Education Policy and Management, 38(6), 595-609.

Gruber, T., Lowrie, A., Brodowsky, G. H., Reppel, A. E., Voss, R., \& Chowdhury, I. N. (2012). Investigating the influence of professor characteristics on student satisfaction and dissatisfaction: A comparative study. Journal of Marketing Education, 34(2), 165-178.

El Hawi, R., \& Alzyadat, W. (2019). TQM measured students' satisfaction in the Jordanians' private university for achieving institutional excellence. TEM Journal, 8(2),409-416

Hailu, H., Mengstu, S., \& Hailu, T. (2018). An integrated continuous improvement model of TPM, TPS and TQM for boosting profitability of manufacturing industries: An innovative model \& guideline. Management Science Letters, 8(1), 33-50.

Herman, J. L., \& Herman, J. J. (1995). Total quality management (TQM) for education. Educational Technology, 35(3), 1418.

Ilies, L., Osoian, C., \& Zaharie, M. (2010). Quality management system in higher education-employers' approach. Managerial Challenges of the Contemporary Society. Proceedings, 75-79.

Inairat, AlKassem (2014), Total quality management in higher education: A Review. International Journal of Human Resource Studies, 4(3), 294-307.

Jusoh, A., Omain, S.Z., Majid, N.A., Som, H.M., \& Shamsuddin, A.S. (2004), Service quality in higher education: Management students' perspective, Research management Center University of technology Malaysia VOT 71982, 1-43. 
Jungblut, J., Vukasovic, M., \& Stensaker, B. (2015). Student perspectives on quality in higher education. European Journal of Higher Education, 5(2), 157-180.

Letcher, D. W., \& Neves, J. S. (2010). Determinants of undergraduate business student satisfaction. Research in Higher Education Journal, 6, 1-26.

Kumar, N.S., Haque, M.I., Venugopal, K. (2019) Employment challenges in Saudi Arabia: an attitudinal study. Entrepreneurship and Sustainability, 6(4), 1637-1646.

Motwani, J., \& Kumar, A. (1997). The need for implementing total quality management in education. International Journal of Educational Management, 11(3), 131-135.

Mihanović, Z., Batinić, A. B., \& Pavičić, J. (2016). The link between students' satisfaction with faculty, overall students' satisfaction with student life and student performances. Review of Innovation and Competitiveness: A Journal of Economic and Social Research, 2(1), 37-60.

Nasim, K., Sikander, A., \& Tian, X. (2020). Twenty years of research on total quality management in Higher Education: A systematic literature review. Higher Education Quarterly, 74(1), 75-97.

De Oliveira, O. J., \& Ferreira, E. C. (2009, May). Adaptation and application of the SERVQUAL scale in higher education. In Proceedings of POMS 20th Annual Conference Orlando, Florida USA: 1-20.

Al-Qahtani, S. S., \& IBN-METHHEB, M. M. (1999). Implementation of total quality management in some Saudi public sector organizations. Economics and Administration, 13(2), 23-38.

Baltaru, R. D. (2019). Do non-academic professionals enhance universities' performance? Reputation vs. organisation. Studies in Higher Education, 44(7), 1183-1196.

Sahney, S., Banwet, D., Karunes, S. (2008) An integrated framework of indices for quality management in education: a faculty perspective. The TQM Journal, 20(5), 502-519.

Sakthivel, P. B., \& Raju, R. (2006). An instrument for measuring engineering education quality from students' perspective. Quality Management Journal, 13(3), 23-34.

Sallis, E (2002). Total Quality Management in Education, $3^{\text {rd }}$ ed., ISBN 0-203-44325-X.

Ho, S. K., \& Wearn, K. (1995). A TQM model for higher education and training. Training for Quality, 3(2) 25-33.

Sangeeta, S., Banwet, D.K., Karunes, S. (2004). Customer requirement constructs: the premise for TQM in education: A comparative study of select engineering and management institutions in the Indian context, International Journal of Productivity and Performance management, 53(6), 499-520.

Siming, L. (2015). Factors leading to students' satisfaction in the higher learning institutions. Journal of Education and Practice, 6(31), 114-118.

Stukalina, Y. (2012) Addressing service quality issues in higher education: the educational environment evaluation from the students' perspective, Technological and Economic Development of Economy, 1, 84-98.

Tausif, M. R., \& Haque, M. I. (2016). Identifying entrepreneurship traits and skills in Saudi Arabia: An attitudinal approach. International Journal of Applied Business and Economic Research, 14(6), 4025-4046.

Tausif, M.R., Haque, M.I. (2019) Changing Market Scenario of Automobile sector in Saudi Arabia, International Journal of Innovative Technology and Exploring Engineering, 8(9), 1-8.

Tausif, M.R. (2017). Assessing the quality of education in Saudi Arabia. International Journal of Economic Research, 14, 521- 528 .

Todorut, A. V. (2013). The need of total quality management in higher education. Procedia-Social and Behavioral Sciences, 83, 1105-1110.

Vision 2030 (2016), https://vision2030.gov.sa/download/file/fid/417

Wani, I. A., \& Mehraj, H. K. (2014). Total quality management in education: An analysis. International Journal of Humanities and Social Science Invention, 3(6), 71-78.

Weerasinghe, I. S., \& Fernando, R. L. (2017). Students' satisfaction in higher education. American Journal of Educational Research, 5(5), 533-539.

Wiklund, H., Klefsjö, B., Wiklund, P. S., \& Edvardsson, B. (2003). Innovation and TQM in Swedish higher education institutions-possibilities and pitfalls. The TQM magazine, 15(2), 99-107

Whitchurch, C. (2008). Shifting identities and blurring boundaries: The emergence of third space professionals in UK higher education. Higher education quarterly, 62(4), 377-396.

Zachariah, S. (2007). Managing quality in higher education: A stakeholder perspective (Doctoral dissertation).

Zulkefli, N., Uden, L., (2013), A Service Quality Framework for Higher Education from the Perspective of Service Dominant Logic. In: Uden L, Herrera F, Bajo Pérez J, Corchado Rodríguez J. (eds) 7th International Conference on Knowledge Management in Organizations: Service and Cloud Computing. Advances in Intelligent Systems and Computing, vol 172. Springer, Berlin, Heidelberg. 


\section{Appendices}

Appendix 1: Analysis of Variance

Table 1a

Descriptive for faculty

\begin{tabular}{ccccccccc}
\hline & $\mathrm{N}$ & Mean & Std. Deviation & Std. Error & \multicolumn{2}{c}{$\begin{array}{c}\text { 95\% Confidence Interval for Mean } \\
\text { Lower Bound }\end{array}$} & Minimum & Maximum \\
\hline 1 & 141 & 0.9291 & 0.33048 & 0.02783 & 0.8741 & 0.9841 & 0 & 3 \\
2 & 241 & 0.3112 & 0.46395 & 0.02989 & 0.2523 & 0.3701 & 0 & 1 \\
3 & 51 & 0.7451 & 0.44014 & 0.06163 & 0.6213 & 0.8689 & 0 & 1 \\
Total & 433 & 0.5635 & 0.51032 & 0.02452 & 0.5153 & 0.6117 & 0 & 3 \\
\hline
\end{tabular}

Table 1b

Results of Analysis of Variance for faculty

\begin{tabular}{cccccc}
\hline & Sum of Squares & df & Mean Square & F & Sig. \\
\hline Between Groups & 35.867 & 2 & 17.933 & 100.622 & \\
Within Groups & 76.637 & 430 & 0.178 & \\
\hline Total & 112.503 & 432 & & \\
\hline
\end{tabular}

Table 1c

Descriptive for faculty

\begin{tabular}{|c|c|c|c|c|c|c|c|c|}
\hline & \multirow[t]{2}{*}{$\mathrm{N}$} & \multirow[t]{2}{*}{ Mean } & \multirow[t]{2}{*}{ Std. Deviation } & \multirow[t]{2}{*}{ Std. Error } & \multicolumn{2}{|c|}{$95 \%$ Confidence Interval for Mean } & \multirow[t]{2}{*}{ Minimum } & \multirow[t]{2}{*}{ Maximum } \\
\hline & & & & & Lower Bound & Upper Bound & & \\
\hline 1 & 158 & 0.7658 & 0.42483 & 0.0338 & 0.6991 & 0.8326 & 0 & 1 \\
\hline 2 & 188 & 0.3617 & 0.514 & 0.03749 & 0.2878 & 0.4357 & 0 & 3 \\
\hline 3 & 87 & 0.6322 & 0.48501 & 0.052 & 0.5288 & 0.7356 & 0 & 1 \\
\hline Total & 433 & 0.5635 & 0.51032 & 0.02452 & 0.5153 & 0.6117 & 0 & 3 \\
\hline
\end{tabular}

Table 1d

Results of Analysis of Variance for staff

\begin{tabular}{ccccc}
\hline & Sum of Squares & df & Mean Square & S \\
\hline Between Groups & 14.534 & 2 & 7.267 & 31.895 \\
Within Groups & 97.97 & 430 & 0.228 & \\
\hline Total & 112.503 & 432 & & \\
\hline
\end{tabular}

Table 1e

Descriptive for systems

\begin{tabular}{|c|c|c|c|c|c|c|c|c|}
\hline & \multirow[t]{2}{*}{$\mathrm{N}$} & \multirow[t]{2}{*}{ Mean } & \multirow[t]{2}{*}{ Std. Deviation } & \multirow[t]{2}{*}{ Std. Error } & \multicolumn{2}{|c|}{ 95\% Confidence Interval for } & \multirow[t]{2}{*}{ Minimum } & \multirow[t]{2}{*}{ Maximum } \\
\hline & & & & & Lower Bound & Upper Bound & & \\
\hline 1 & 182 & 0.7747 & 0.45677 & 0.03386 & 0.7079 & 0.8415 & 0 & 3 \\
\hline 2 & 170 & 0.3588 & 0.48107 & 0.0369 & 0.286 & 0.4317 & 0 & 1 \\
\hline 3 & 81 & 0.5185 & 0.50277 & 0.05586 & 0.4073 & 0.6297 & 0 & 1 \\
\hline Total & 433 & 0.5635 & 0.51032 & 0.02452 & 0.5153 & 0.6117 & 0 & 3 \\
\hline
\end{tabular}

Table1f

Results of Analysis of Variance for systems

\begin{tabular}{ccccc}
\hline & Sum of Squares & df & Mean Square & F \\
\hline Between Groups & 15.406 & 2 & 7.703 & 34.112 \\
Within Groups & 97.098 & 430 & 0.226 & \\
\hline Total & 112.503 & 432 &
\end{tabular}


Appendix B

Results of Binary Logistic regression

Table 2a

Case Processing Summary

\begin{tabular}{|c|c|c|c|}
\hline \multicolumn{2}{|c|}{ Unweighted Cases a } & $\mathrm{N}$ & Percent \\
\hline \multirow[t]{4}{*}{ Selected Cases } & Included in Analysis & 433 & 100 \\
\hline & Missing Cases & 0 & 0 \\
\hline & Total & 433 & 100 \\
\hline & Unselected Cases & 0 & 0 \\
\hline \multicolumn{2}{|c|}{ Total } & 433 & 100 \\
\hline
\end{tabular}

If weight is in effect, see classification table for the total number of cases.

Table 2b

Dependent Variable Encoding

\begin{tabular}{ccc} 
Original Value & Internal Value \\
\cline { 2 - 3 } & 0 & 0 \\
1 & 1 \\
\hline
\end{tabular}

Table 2c

Categorical Variables Codings

\begin{tabular}{|c|c|c|c|c|}
\hline & & \multirow[b]{2}{*}{ Frequency } & \multicolumn{2}{|c|}{ Parameter coding } \\
\hline & & & -1 & -2 \\
\hline \multirow[t]{3}{*}{ System } & 1 & 141 & 1 & 0 \\
\hline & 2 & 241 & 0 & 1 \\
\hline & 3 & 51 & 0 & 0 \\
\hline \multirow[t]{3}{*}{ Staff } & 1 & 158 & 1 & 0 \\
\hline & 2 & 188 & 0 & 1 \\
\hline & 3 & 87 & 0 & 0 \\
\hline \multirow[t]{3}{*}{ Faculty } & 1 & 182 & 1 & 0 \\
\hline & 2 & 170 & 0 & 1 \\
\hline & 3 & 81 & 0 & 0 \\
\hline
\end{tabular}

Block 0: Beginning Block

Table 2c

Classification Tables a,b

\begin{tabular}{|c|c|c|c|c|c|}
\hline & & & \multicolumn{3}{|c|}{ Predicted } \\
\hline & & & \multicolumn{2}{|c|}{ Satisfaction } & \multirow[b]{2}{*}{ Percentage Correct } \\
\hline & \multicolumn{2}{|c|}{ Observed } & 0 & 1 & \\
\hline \multirow[t]{3}{*}{ Step 0} & Satisfaction & 0 & 0 & 192 & 0 \\
\hline & & 1 & 0 & 241 & 100 \\
\hline & \multicolumn{2}{|c|}{ Overall Percentage } & & & 55.7 \\
\hline
\end{tabular}

a. Constant is included in the model.

b. The cut value is .500

Table 2d

Variables in the Equation

\begin{tabular}{cccccccc}
\hline & B & S.E. & Wald & df & Sig. & Exp(B) \\
\hline Step 0 & Constant & 0.227 & 0.097 & 5.521 & 1 & 0.019 & 1.255 \\
\hline
\end{tabular}

Table 2d

Variables not in the Equation

\begin{tabular}{|c|c|c|c|c|c|}
\hline & & & Score & df & Sig. \\
\hline \multirow[t]{10}{*}{ Step 0} & \multirow[t]{9}{*}{ Variables } & Faculty & 57.404 & 2 & 0 \\
\hline & & Faculty(1) & 51.735 & 1 & 0 \\
\hline & & Faculty(2) & 44.352 & 1 & 0 \\
\hline & & Staff & 63.906 & 2 & 0 \\
\hline & & Staff(1) & 44.133 & 1 & 0 \\
\hline & & $\operatorname{Staff}(2)$ & 59.846 & 1 & 0 \\
\hline & & System & 136.615 & 2 & 0 \\
\hline & & System(1) & 104.505 & 1 & 0 \\
\hline & & System(2) & 132.597 & 1 & 0 \\
\hline & \multicolumn{2}{|c|}{ Overall Statistics } & 161.849 & 6 & 0 \\
\hline
\end{tabular}

Block 1: Method $=$ Enter 
Table 2e

Omnibus Tests of Model Coefficients

\begin{tabular}{ccccc}
\hline & & Chi-square & df & \\
\hline Step 1 & Step & 187.174 & 6 & \\
& Block & 187.174 & 6 & 0 \\
& Model & 187.174 & 6 & 0 \\
\hline
\end{tabular}

Table $2 f$

Model Summary

\begin{tabular}{|c|c|c|c|}
\hline Step & -2 Log likelihood & Cox \& Snell R Square & Nagelkerke R Square \\
\hline 1 & $407.534 \mathrm{a}$ & 0.351 & 0.47 \\
\hline
\end{tabular}

Table 2g

Hosmer and Lemeshow Test

\begin{tabular}{ccccc}
\hline Step & Chi-square & df & Sig. & \\
\hline 1 & 3.921 & 6 & 0.687 & \\
\hline
\end{tabular}

Table 2h

Contingency Table for Hosmer and Lemeshow Test

\begin{tabular}{|c|c|c|c|c|c|c|}
\hline & & \multicolumn{2}{|c|}{ Satisfaction $=.00$} & \multicolumn{2}{|c|}{ Satisfaction $=1.00$} & \multirow[b]{2}{*}{ Total } \\
\hline \multirow{9}{*}{ Step 1} & & Observed & Expected & Observed & Expected & \\
\hline & 1 & 74 & 74.158 & 15 & 14.842 & 89 \\
\hline & 2 & 33 & 30.129 & 7 & 9.871 & 40 \\
\hline & 3 & 29 & 31.504 & 20 & 17.496 & 49 \\
\hline & 4 & 20 & 22.564 & 22 & 19.436 & 42 \\
\hline & 5 & 21 & 17.305 & 30 & 33.695 & 51 \\
\hline & 6 & 7 & 7.901 & 31 & 30.099 & 38 \\
\hline & 7 & 4 & 4.973 & 42 & 41.027 & 46 \\
\hline & 8 & 4 & 3.465 & 74 & 74.535 & 78 \\
\hline
\end{tabular}

Table 2i

Classification Table

\begin{tabular}{|c|c|c|c|c|c|}
\hline & & & \multicolumn{3}{|c|}{ Predicted } \\
\hline & & & \multicolumn{2}{|c|}{ Satisfaction } & \multirow[b]{2}{*}{ Percentage Correct } \\
\hline \multirow{4}{*}{ Step 1} & \multicolumn{2}{|c|}{ Observed } & 0 & 1 & \\
\hline & Satisfaction & 0 & 150 & 42 & 78.1 \\
\hline & & 1 & 50 & 191 & 79.3 \\
\hline & Overall Percentage & & & & 78.8 \\
\hline
\end{tabular}

a. The cut value is .500

Table 2j

CasewiseList

\begin{tabular}{|c|c|c|c|c|c|c|}
\hline \multicolumn{4}{|c|}{ Observed } & \multicolumn{3}{|c|}{ Temporary Variable } \\
\hline Case & Selected Statusa & Satisfaction & Predicted & Predicted Group & Resid & ZResid \\
\hline 151 & $\mathrm{~S}$ & $0^{* *}$ & 0.957 & 1 & $-.957-$ & $-4.699-$ \\
\hline 188 & $\mathrm{~S}$ & $0 * *$ & 0.868 & 1 & -.868 & $-2.567-$ \\
\hline 239 & $\mathrm{~S}$ & $0 * *$ & 0.957 & 1 & $-.957-$ & $-4.699-$ \\
\hline 240 & $\mathrm{~S}$ & $0 * *$ & 0.957 & 1 & $-.957-$ & $-4.699-$ \\
\hline 241 & $\mathrm{~S}$ & $0 * *$ & 0.957 & 1 & $-.957-$ & $-4.699-$ \\
\hline 259 & $\mathrm{~S}$ & $0 * *$ & 0.868 & 1 & $-.868-$ & $-2.567-$ \\
\hline 277 & $\mathrm{~S}$ & $0 * *$ & 0.889 & 1 & -.889 & $-2.830-$ \\
\hline 376 & $\mathrm{~S}$ & $0 * *$ & 0.887 & 1 & $-.887-$ & $-2.806-$ \\
\hline 378 & $\mathrm{~S}$ & $0 * *$ & 0.887 & 1 & $-.887-$ & $-2.806-$ \\
\hline 402 & $\mathrm{~S}$ & $0 * *$ & 0.868 & 1 & $-.868-$ & $-2.567-$ \\
\hline 410 & $\mathrm{~S}$ & $0 * *$ & 0.889 & 1 & -.889- & $-2.830-$ \\
\hline
\end{tabular}

a. $\mathrm{S}=$ Selected, $\mathrm{U}=$ Unselected cases, and $* *=$ Misclassified cases.

b. Cases with studentized residuals greater than 2.000 are listed. 
(C) 2020 by the authors; licensee Growing Science, Canada. This is an open access article distributed under the terms and conditions of the Creative Commons Attribution (CC-BY) license (http://creativecommons.org/licenses/by/4.0/). 